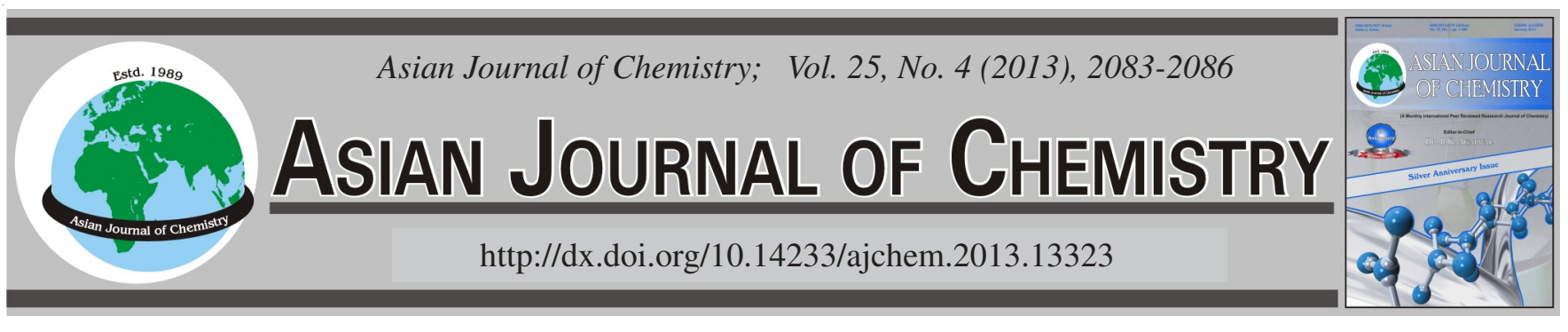

\title{
Synthesis, Characterization and Biological Activity of Schiff Base Complexes of Sulfa Drug with Transition Metals
}

\author{
V. Gomathi* and R. SElVAmeEnA
}

Post Graduate and Research Department of Chemistry, Seethalakshmi Ramaswami College, Tiruchirappalli-620 002, India

*Corresponding author: E-mail: vemathi@gmail.com; rsmchemsrc@gmail.com

The Schiff base has been prepared by refluxing sulfa pyridine with 2-hydroxynaphthaldehyde in ethanolic media and then complexed with $\mathrm{Co}(\mathrm{II}), \mathrm{Ni}(\mathrm{II}), \mathrm{Cu}(\mathrm{II}), \mathrm{Zn}(\mathrm{II})$ and $\mathrm{Mn}(\mathrm{II})$ metal ions. The synthesized ligand and complexes were characterized by elemental analysis, molar conductances, magnetic moments, IR, ${ }^{1} \mathrm{H}$ NMR and electronic spectral data. The spectral data of the complexes have revealed bidentate complexing nature of the Schiff base ligand through phenolic oxygen and azomethine nitrogen atoms. The antibacterial and antifungal activity of the Schiff base and its complexes have also been screened. All the metal complexes possess significant to moderate activity and the metal complexes exhibit more activity against various species compared to the Schiff base.

Key Words: Sulfa drug, Schiff base, Metal complexes, Antibacterial, Antifungal.

\section{INTRODUCTION}

The sulfa drugs, first effective chemotherapeutic agents are widely used for the cure of bacterial infection in humans. Sulphanilamide is found to be active against several types of bacteria and hence used in the treatment of diseases like pneumonia, gonorrhoea, meningitis, tonsillitis, sinus infections ${ }^{1}$ etc.

Nowadays Schiff bases are attracting the biochemists as they are known to be biologically important and are used to design medicinal compounds ${ }^{2}$. The azomethine ( $\left.>\mathrm{C}=\mathrm{N}-\right)$ linkage in Schiff bases play an important role in elucidating the mechanism of transamination and resamination reactions in biological systems ${ }^{3,4}$. The biomedicinal properties of free organic molecules depend upon chelation with suitable metal ions leading to the implementation of metal complexes for several biomedical applications as therapeutically active, possessing analgesic ${ }^{5}$, antipyretic ${ }^{6}$, antiinflammatory ${ }^{7}$, cytotoxic $^{8}$, antiviral $^{9}$, antitumorous ${ }^{10}$ and antitubercular ${ }^{11}$ activity besides their applications as antimicrobial agents ${ }^{12}$. The direct use of transition metal salts, as antimicrobial agents cannot be recommended as they are toxic to both the microbes and the host animals. Metal ions play a catalytic role in reactions of Schiff bases. Aromatic Schiff bases and their complexes catalyze reactions of the type oxygenation ${ }^{13}$, hydrolysis ${ }^{14}$, electroreduction ${ }^{15}$ and decomposition ${ }^{16}$. Th(IV) and $\mathrm{UO}_{2}(\mathrm{VI})$ complexes of Schiff base obtained from 2-nitro benzaldehyde and 2-amino pyridine show toxic effects to bacterial and fungal genus ${ }^{17} . \mathrm{Mn}(\mathrm{II})$, $\mathrm{Ni}(\mathrm{II}), \mathrm{Cu}(\mathrm{II})$ and $\mathrm{Zn}$ (II) complexes of the chlorobenzaldehyde
Schiff base of S-benzyl esters of the dithiocarbazoic acid are biologically active ${ }^{18}$. Ni(II) and $\mathrm{Co}(\mathrm{II})$ complexes of 2hydroxynaphthylidene-2-aminophenol inhibit the growth of bacterial strains of Escherichia coli and Bacillus substills ${ }^{19}$. Salicyliden and 2-hydroxynaphthylideneamines have been the subject of particular interest because some of their complexes are found in nature and biological activities have been recorded for the synthesized ones ${ }^{20}$. In view of the importance of coordination compounds in medicinal chemistry ${ }^{21}$, the present paper reports the synthesis, characterisation and biological studies on $\mathrm{Co}(\mathrm{II}), \mathrm{Ni}(\mathrm{II}), \mathrm{Cu}(\mathrm{II}), \mathrm{Zn}$ (II) and $\mathrm{Mn}$ (II) complexes of Schiff base derived from sulfa pyridine and 2-hydroxynaphthaldehyde.

\section{EXPERIMENTAL}

All the reagents used were of AR grade (BDH/E. Merck). Solvents were purified and dried according to the standard procedures. Elemental analysis $(\mathrm{C}, \mathrm{H}, \mathrm{N})$ were performed using elemental analyser. IR spectra of the ligand and its complexes were recorded in $\mathrm{KBr}$ pellets with Perkin Elmer IR RXI Spectrometer in the $4000-400 \mathrm{~cm}^{-1}$ range. The ${ }^{1} \mathrm{H}$ NMR spectra were recorded on a Bruker $400 \mathrm{MHz}$ FT-PMR spectrometer (DMSO- $d_{6}$ ). Magnetic susceptibilities were determined with a magnetic susceptibility meter (MSB-Auto). Melting points were determined using Elico melting point apparatus. The electronic spectra were recorded in Perkin Elmer Lambda 35 spectrometer in the 190-1100 nm range.Conductivity measu- 
rements for the complexes were carried out using Elico conductivity bridge and dip type conductivity cell.

Synthesis of Schiff Base (HNSP): To a hot stirred solution of sulfapyridine $(0.0025 \mathrm{~mol})$ in ethanol was added a solution of 2-hydroxy naphthaldehyde $(0.0025 \mathrm{~mol})$ in ethanol. The reaction mixture was refluxed for $4 \mathrm{~h}$. The yellow coloured solid mass formed during refluxing was cooled to room temperature, filtered and washed thoroughly with ethanol. The purity of the ligand was checked by TLC. (m.p. $238^{\circ} \mathrm{C}$; yield $82 \%)$.

General method for preparation of metal complexes: To a hot magnetically stirred dioxane $(25 \mathrm{~mL})$ solution of Schiff base $(0.002 \mathrm{~mol})$, an aqueous solution of the corresponding metal(II) chloride $(0.001 \mathrm{~mol})$ was added. The mixture was refluxed for 4-5 $\mathrm{h}$ on a water bath. The precipitates formed during refluxing were cooled in an ice bath and collected by suction filtration, washed with small amount of dioxane and dried. The coloured solids obtained are mostly insoluble in some common organic solvents and soluble in polar solvents like DMF and DMSO. The yield of the ligand and its metal complexes together with colour, analytical data and other physical properties are reported in Table-1.

\section{RESULTS AND DISCUSSION}

Analytical data: The analytical data obtained for the ligand and complexes (Table-1) agree very well with the proposed molecular formulae and also indicates the formation of 1:2 (M:L) complexes of general formula of [M(HNSP) $\left.)_{2} \mathrm{Cl}_{2}\right]$ $\left[\mathrm{M}=\mathrm{Co}^{2+}, \mathrm{Ni}^{2+}, \mathrm{Cu}^{2+}, \mathrm{Zn}^{2+}\right.$ and $\left.\mathrm{Mn}^{2+}\right]$.

Conductance and magnetic susceptibility measurements: The observed molar conductance of all the complexes in $10^{-3} \mathrm{M}$ DMF solutions are found within the range 4.9-13.8 $\mathrm{ohm}^{-1} \mathrm{~cm}^{2} \mathrm{~mol}^{-1}$ showing their non-electrolytic nature. This in turn suggests that the chloride ions are coordinated with the metal ions and present inside the coordination sphere in all the complexes. The observed magnetic moment around 3.0 $\mathrm{BM}$ for the $\mathrm{Co}$ (II) and $\mathrm{Ni}$ (II) complexes is consistent with octahedral geometry around the metal ion for both the complexes. The magnetic moment value of $1.80 \mathrm{BM}$ measured for the $\mathrm{Cu}(\mathrm{II})$ complex lies in the range expected for $d^{9}$ system, which contains one unpaired electron with octahedral geometry $^{22}$. The $\mathrm{Zn}$ (II) complex is found to be diamagnetic as expected. The observed magnetic moment value of 5.76 BM for the $\mathrm{Mn}$ (II) complex suggests octahedral geometry.

IR Spectra: The IR spectral bands of Schiff base and its metal complexes are given in Table-2. The Schiff base contains five potential donor sites (i) the phenolic oxygen (ii) the azomethine nitrogen (iii) the sulphonamide oxygen (iv) the sulphonamide nitrogen and (v) ring nitrogen ${ }^{23}$. In the IR spectrum of the Schiff base ligand, a band is observed at 1618 $\mathrm{cm}^{-1}$ that is assigned to the $>\mathrm{C}=\mathrm{N}$ - stretching mode. This band shifts to lower frequency by $6-26 \mathrm{~cm}^{-1}$ after complexation except for $\mathrm{Zn}(\mathrm{II})$ complex where the band shifts to higher frequency by $6 \mathrm{~cm}^{-1}$, indicating the coordination of azomethine nitrogen to metal ion. A medium broad band observed at 3428 $\mathrm{cm}^{-1}$ in the Schiff base indicates the presence of phenolic oxygen. The shift of this frequency in complexes by $5-33 \mathrm{~cm}^{-1}$ indicates coordination through phenolic oxygen. The bands in the ligand due to $\mathrm{v}_{\mathrm{as}}\left(\mathrm{SO}_{2}\right)$ and $\mathrm{v}_{\mathrm{s}}\left(\mathrm{SO}_{2}\right)$ appear at 1133 and $1358 \mathrm{~cm}^{-1}$, respectively. These bands almost remain unchanged in the complexes indicating that this $-\mathrm{SO}_{2}$ group is not participating in coordination. This is confirmed by the unchanged $v(\mathrm{~S}-\mathrm{N})$ and $v(\mathrm{C}-\mathrm{S})$ modes appearing around 959 and $826 \mathrm{~cm}^{-1}$, respectively. The ring nitrogen $(=\mathrm{N}-$ ) of the Schiff base does not take part in coordination, supported by unchanged band around $1275 \mathrm{~cm}^{-1}$. The coordination of phenolic oxygen and azomethine nitrogen is further supported by the appearance of two non ligand bands in the region 480-432 and 568$547 \mathrm{~cm}^{-1}$ due to $v(\mathrm{M}-\mathrm{O})$ and $\mathrm{v}(\mathrm{M}-\mathrm{N})$, respectively in all the complexes $^{24}$.

${ }^{1} \mathbf{H}$ NMR spectra: ${ }^{1} \mathrm{H}$ NMR spectra of free ligand and its $\mathrm{Co}$ (II) complex were recorded in DMSO- $d_{6}$. The ligand showed peak at $\delta=8.9 \mathrm{ppm}$, suggests the presence of $-\mathrm{CH}=\mathrm{N}$ - linkage. The peaks at $\delta=15.3 \mathrm{ppm}$ and $6.53-8.49 \mathrm{ppm}$ indicate hydroxyl proton and aromatic proton. The ${ }^{1} \mathrm{H}$ NMR spectra of complexes apparently provides following two informations, regarding complexation.

TABLE-1

PHYSICAL CHARACTERISTICS AND ANALYTICAL DATA OF SCHIFF BASE AND THE COMPLEXES

\begin{tabular}{|c|c|c|c|c|c|c|c|c|}
\hline \multirow{2}{*}{$\begin{array}{l}\text { Schiff base and } \\
\text { complexes }\end{array}$} & \multirow{2}{*}{ Colour } & \multicolumn{3}{|c|}{ Elemental analysis (\%) found (calcd.) } & \multirow{2}{*}{$\begin{array}{l}\text { m.p. } \\
\left({ }^{\circ} \mathrm{C}\right)\end{array}$} & \multirow{2}{*}{$\begin{array}{l}\text { Yield } \\
(\%)\end{array}$} & \multirow{2}{*}{$\begin{array}{l}\text { Molar conductance } \\
\left(\mathrm{ohm}^{-1} \mathrm{~cm}^{2} \mathrm{~mol}^{-1}\right)\end{array}$} & \multirow{2}{*}{$\begin{array}{c}\text { Magnetic } \\
\text { moment }(\mathrm{BM})\end{array}$} \\
\hline & & $\mathrm{C}$ & $\mathrm{H}$ & $\mathrm{N}$ & & & & \\
\hline HNSP & Yellow & 65.59 (65.50) & $3.74(4.22)$ & 10.47 (10.42) & 238 & 62 & - & - \\
\hline$\left[\mathrm{Co}(\mathrm{HNSP})_{2} \mathrm{Cl}_{2}\right]$ & Light yellow & $57.05(56.54)$ & $2.91(3.43)$ & $8.26(8.99)$ & 261 & 78 & 7.9 & 3.56 \\
\hline$\left[\mathrm{Ni}(\mathrm{HNSP})_{2} \mathrm{Cl}_{2}\right]$ & Cream & $57.14(56.55)$ & $3.88(3.43)$ & $9.85(9.00)$ & 252 & 60 & 11.8 & 3.13 \\
\hline$\left[\mathrm{Cu}(\mathrm{HNSP})_{2} \mathrm{Cl}_{2}\right]$ & Green & $56.56(56.26)$ & $3.02(3.41)$ & $8.41(8.95)$ & 258 & 72 & 13.8 & 1.80 \\
\hline$\left[\mathrm{Zn}(\mathrm{HNSP})_{2} \mathrm{Cl}_{2}\right]$ & Orange & $56.67(56.15)$ & $3.55(3.40)$ & $9.20(8.93)$ & 268 & 59 & 4.9 & dia \\
\hline$\left[\mathrm{Mn}(\mathrm{HNSP})_{2} \mathrm{Cl}_{2}\right]$ & Cream & $56.33(56.78)$ & $2.90(3.44)$ & $8.60(9.03)$ & 245 & 53 & 6.9 & 5.76 \\
\hline
\end{tabular}

TABLE-2

INFRA RED AND ELECTRONIC ABSORPTION SPECTRAL DATA OF SCHIFF BASE AND THE COMPLEXES

\begin{tabular}{|c|c|c|c|c|c|}
\hline \multirow{2}{*}{$\begin{array}{l}\text { Schiff base and } \\
\text { complexes }\end{array}$} & \multicolumn{4}{|c|}{ Key, IR bands $\left(\mathrm{cm}^{-1}\right)$} & \multirow{2}{*}{ UV-VIS $\left(\mathrm{cm}^{-1}\right)$} \\
\hline & $v(\mathrm{OH})$ & $\mathrm{v}(>\mathrm{C}=\mathrm{N})$ & $\mathrm{v}(\mathrm{M}-\mathrm{O})$ & $v(\mathrm{M}-\mathrm{N})$ & \\
\hline HNSP & 3428 & 1618 & - & - & - \\
\hline$\left[\mathrm{Co}(\mathrm{HNSP})_{2} \mathrm{Cl}_{2}\right]$ & 3433 & 1592 & 450 & 568 & 21596,27246 \\
\hline$\left[\mathrm{Ni}(\mathrm{HNSP})_{2} \mathrm{Cl}_{2}\right]$ & 3445 & 1600 & 480 & 547 & $36274,35237,23762,25643,26137$ \\
\hline$\left[\mathrm{Cu}(\mathrm{HNSP})_{2} \mathrm{Cl}_{2}\right]$ & 3457 & 1612 & 458 & 563 & $36260,34509,26818$ \\
\hline$\left[\mathrm{Zn}(\mathrm{HNSP})_{2} \mathrm{Cl}_{2}\right]$ & 3395 & 1624 & 432 & 564 & $36490,30840,25922$ \\
\hline$\left[\mathrm{Mn}(\mathrm{HNSP})_{2} \mathrm{Cl}_{2}\right]$ & 3439 & 1605 & 465 & 565 & $32350,31460,27268,25370$ \\
\hline
\end{tabular}


TABLE-3

ANTIMICROBIAL ACTIVITY OF SCHIFF BASE AND COMPLEXES

\begin{tabular}{lcccc}
\hline \multicolumn{1}{c}{ Antimicrobial activity of the } & Staphylococcus aureus & Pseudomonas aeruginosa & Candida albicans & Aspergillus niger \\
\hline $\mathrm{HNSP}$ & ++ & ++ & ++ & ++ \\
{$\left[\mathrm{Co}(\mathrm{HNSP})_{2} \mathrm{Cl}_{2}\right]$} & ++ & ++ & +++ & ++ \\
{$\left[\mathrm{Ni}(\mathrm{HNSP})_{2} \mathrm{Cl}_{2}\right]$} & +++ & +++ & +++ & ++ \\
{$\left[\mathrm{Cu}(\mathrm{HNSP})_{2} \mathrm{Cl}_{2}\right]$} & ++ & +++ & +++ & ++ \\
{$\left[\mathrm{Zn}(\mathrm{HNSP})_{2} \mathrm{Cl}_{2}\right]$} & +++ & +++ & +++ & ++ \\
{$\left[\mathrm{Mn}(\mathrm{HNSP})_{2} \mathrm{Cl}_{2}\right]$} & +++ & +++ & +++ & +++ \\
\hline $\mathrm{Sl}$ & & ++ & ++ \\
\hline
\end{tabular}

Standard = Ciprofloxacin $5 \mu \mathrm{g} /$ disc for bacteria; Nystatin $=100$ units/disc for fungi. Highly active $=+++$ (inhibition zone $>15 \mathrm{~mm}$ ); moderatively active $=++($ inhibition zone $>10 \mathrm{~mm})$; slightly active $=+$ (inhibition zone $>5 \mathrm{~mm})$; inactive $=-(<5 \mathrm{~mm})$.

The disappearance of peak at $\delta=15.3 \mathrm{ppm}$ indicates the deprotonation of hydroxyl proton due to co-ordination of oxygen to the metal ${ }^{25}$.

The coordination of the azomethine nitrogen is inferred by the upfield shifting of the $-\mathrm{CH}=\mathrm{N}$ proton signal from 8.9 ppm in the ligand to 8.25-8.45 ppm in the complexes.

Electronic spectra: The electronic spectra of the Schiff base and its metal complexes were recorded in DMSO and given in Table-2. The Co(II) complexes exhibited high energy band at $21596 \mathrm{~cm}^{-1}$ which is assigned to the transition ${ }^{4} \mathrm{~T}_{1 \mathrm{~g}}(\mathrm{~F})$ $\rightarrow{ }^{4} \mathrm{~T}_{1 \mathrm{~g}}(\mathrm{P})$ for a high spin octahedral geometry. A band at 27246 $\mathrm{cm}^{-1}$ is assigned to ${ }^{4} \mathrm{~T}_{1 \mathrm{~g}}(\mathrm{~F}) \rightarrow{ }^{4} \mathrm{~A}_{2 \mathrm{~g}}(\mathrm{~F})$ transition. The Ni(II) complex exhibited five absorption bands at 36274, 35237, 23762,25643 and $26137 \mathrm{~cm}^{-1}$. The two bands at 36274 and $35237 \mathrm{~cm}^{-1}$ may be attributed to $\mathrm{L} \rightarrow \mathrm{M}$ charge-transfer transitions. The bands in the region around $25000 \mathrm{~cm}^{-1} \mathrm{can}$ be assigned to ${ }^{3} \mathrm{~A}_{2 \mathrm{~g}}(\mathrm{~F}) \rightarrow{ }^{3} \mathrm{~T}_{1 \mathrm{~g}}(\mathrm{P}) \mathrm{d}-\mathrm{d}$ transition. This suggests octahedral geometry around $\mathrm{Ni}(\mathrm{II})$ ion. The $\mathrm{Cu}(\mathrm{II})$ complex exhibited three bands at 36260,34509 and $26818 \mathrm{~cm}^{-1}$. The band at 26818 $\mathrm{cm}^{-1}$ is due to ${ }^{2} \mathrm{E}_{\mathrm{g}} \rightarrow{ }^{2} \mathrm{~T}_{2 \mathrm{~g}}$ transition. The bands at 36260 and $34509 \mathrm{~cm}^{-1}$ are due to $\mathrm{L} \rightarrow \mathrm{M}$ charge transfer transitions. The $\mathrm{Zn}$ (II) complex exhibited three absorption bands at 36490 , 30840 and $25922 \mathrm{~cm}^{-1}$, due to $\mathrm{L} \rightarrow \mathrm{M}$ charge transfer transitions. The Mn(II) complex had bands at 25370 and $27268 \mathrm{~cm}^{-1}$ which may be due to ${ }^{6} \mathrm{~A}_{1 \mathrm{~g}} \rightarrow{ }^{4} \mathrm{E}_{\mathrm{g}}$ and ${ }^{6} \mathrm{~A}_{\mathrm{gg}} \rightarrow{ }^{4} \mathrm{~T}_{2 \mathrm{~g}}$ (D) transitions, respectively whereas the bands at 32350 and $31460 \mathrm{~cm}^{-1}$ may be due to $\mathrm{M} \rightarrow \mathrm{L}$ charge transfer transitions.

On the basis of foregoing evidences, the structure proposed for the complex is as follows.

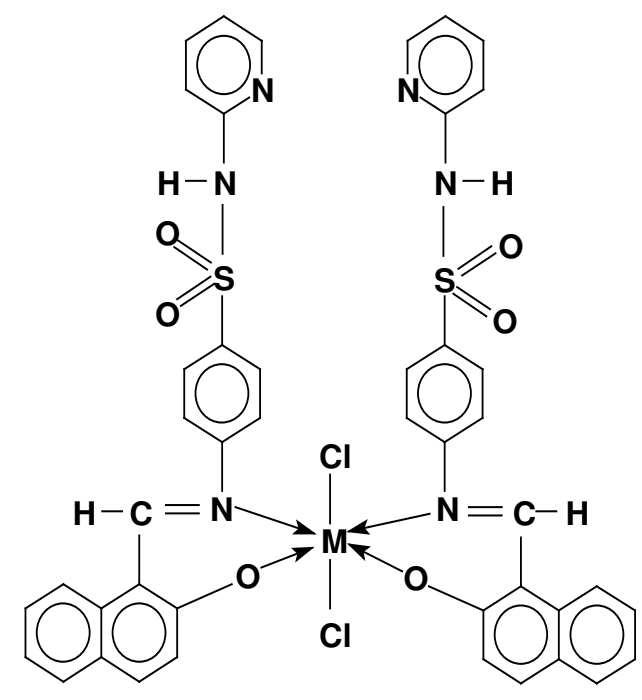

Antibacterial activity: The synthesized Schiff base and its metal(II) complexes were screened in vitro for antibacterial activity against gram positive (Staphylococcus aureus) and gram negative (Pseudomonas aeruginosa) bacterial strains using the disc diffusion technique. The test was carried out in DMSO solution at a concentration of $100 \mathrm{ppm}$ using Muller Hinton agar media. Ciprofloxacin was used as the standard drug. $\left[\mathrm{Ni}(\mathrm{HNSP})_{2} \mathrm{Cl}_{2}\right],\left[\mathrm{Zn}(\mathrm{HNSP})_{2} \mathrm{Cl}_{2}\right]$ and $\left[\mathrm{Mn}(\mathrm{HNSP})_{2} \mathrm{Cl}_{2}\right]$ exhibit significant activity against Staphylococcus aureus and Pseudomonas aeruginosa, $\left[\mathrm{Cu}(\mathrm{HNSP})_{2} \mathrm{Cl}_{2}\right]$ exhibit significant activity against $P$ seudomonas aeruginosa and moderate activity against Staphylococcus aureus. (HNSP) and $\left[\mathrm{Co}\left(\mathrm{HNSP}_{2} \mathrm{Cl}_{2}\right]\right.$ show moderate activity against both Staphylococcus aureus and Pseudomonas aeruginosa (Table-3).

Antifungal activity: Antifungal activity of Schiff base and metal complexes were studied against two fungal cultures Candida albicans and Aspergillus niger species at concentration of 100 ppm using Sabouraud dextrose agar media disc diffusion technique ${ }^{22}$. Nystatin was used as the standard drug. $\left[\mathrm{Co}(\mathrm{HNSP})_{2} \mathrm{Cl}_{2}\right],\left[\mathrm{Zn}(\mathrm{HNSP})_{2} \mathrm{Cl}_{2}\right]$ and $\left[\mathrm{Mn}(\mathrm{HNSP})_{2} \mathrm{Cl}_{2}\right]$ show significant activity against Candida albicans and Aspergillus niger. $\left[\mathrm{Cu}(\mathrm{HNSP})_{2} \mathrm{Cl}_{2}\right]$ and $\left[\mathrm{Ni}(\mathrm{HNSP})_{2} \mathrm{Cl}_{2}\right]$ show significant activity against $C$ andida albicans and moderate activity against Aspergillus niger. The Schiff base HNSP exhibit moderate activity against both Candida albicans and Aspergillus niger. Here it is evident that overall potency of uncoordinated compound is enhanced on coordination with metal ions ${ }^{22}$. However the $\mathrm{Zn}$ (II) and $\mathrm{Mn}$ (II) complexes were observed to be the most active against various species (Table-3).

\section{ACKNOWLEDGEMENTS}

The authors are thankful to University Grants Commission, Hyderabad, India, for the financial support.

\section{REFERENCES}

1. R.C. Maurya and P. Patel, Spectrosc. Lett., 32, 213 (1999).

2. I. Sakiyan, E. Logoglu, S. Arsalan, N. Sari and N. Sakiyan, Biometals, 17, 115 (2004).

3. K.Y. Lau, A. Mayr and K.K. Cheung, Inorg. Chim. Acta, 285, 233 (1999).

4. P.P. Dholakiya and M.N. Patel, Synth. React. Inorg. Met. Org. Chem., 34, 553 (2004).

5. R. Nirmal, C.R. Prakesh, K. Menakshi and P. Shanmugapandiyan, J. Young Pharm., 2, 162 (2010).

6. P. Mondol, M. Banerjee, S. Jana and A. Bose, J. Young Pharmacists, 2, 169 (2010).

7. E. Pontiki, D.H. Litina and A.T. Chaviara, J. Enzym. Med. Chem., 23, 1011 (2008). 
8. S. Kumar, D.P. Matharasi, S. Gopi, S. Sivakumar and S. Narasimhan, J. Asian Nat. Prod. Res., 12, 360 (2010).

9. P.H. Wang, J.G. Keck, K.J. Lien and M.M.C. Lai, J. Med. Chem., 33, 608 (1990).

10. S. Tushar, B. Baul, S. Basu, D.de Vos and A. Linden, Investig. New Drugs, 27, 419 (2008).

11. W.S. Abdel-Aal, H.Y. Hassan, T. Aboul-Fadl and A.F. Youssef, Eur. J. Med. Chem., 45, 1098 (2010).

12. F.M. Morad, M.M.EL, Ajaily and S. Ben Gweirif, J. Sci. Appl., 1, 72 (2007).

13. A. Nishinaga, T. Yamada, H. Fujisawa and K. Ishizaki, J. Mol. Catal., 48, 249 (1988); Chem. Abstr., 111, 22902 (1989).

14. H. Chakraborty, N. Paul and M.L. Rahman, Transition Met. Chem., 19, 524 (1994).

15. Y.D. Zaho, D.W. Pang, Z. Zong, J.K. Cheng, Z.F. Luo, C.J. Fren, H.Y Shen and X.C. Zhung, Huaxe Xuebao, 56, 178 (1988); Chem Abstr., 128, 252661 (1998).
16. R. Sreekala, K.K. Yusuff and Mohammed, Chem. Abstr., 130, 115551 (1999).

17. S. Agnihotri and K. Arora, Asian J. Chem., 22, 5125 (1999).

18. S. Shrivastava, A. Kumar, Y. Pandey, S.N. Dikshit, M. Shrivastava and D.K. Agarwal, Asian J. Chem., 22, 5187 (2010).

19. K.J. Boney Victory, K.U. Sherin and M.K. Muraleedharan Nair, Res. J. Pharm. Biol. Chem. Sci., 1, 324 (2010).

20. H. Temel, T. Taskin and M. Sekerci, Russ. J. Inorg. Chem., 49, 347 (2004).

21. D.X. West, S.B. Padhye, P.B. Sonawane and R.C. Chikte, Struct. Bonding, 76, 1 (1991).

22. J.H. Chohan and M.M. Naseer, Appl. Organomet. Chem., 21, 728 (2007).

23. R.C. Maurya, P. Patel and S. Rajput, Synth. React. Inorg. Met.-Org. Chem., 33, 801 (2003).

24. J.H. Deshmukh and M.N. Deshpande, Asian J. Chem., 22, 5961 (2010).

25. V.L. Chavan and B.H. Mehta, Asian J. Chem., 22, 5976 (2010). 